\title{
THE PROBLEMS OF MICROCLIMATE IN LITHUANIAN COWSHEDS
}

Rolandas BLEIZGYS, Institute of Energy and Biotechnology Engineering, Agriculture Academy, Vytautas Magnus University, K. Donelaičio g. 58, LT-44248 Kaunas, Lithuania. rolandas.bleizgys@ vdu.lt (corresponding author)

Indrė BAGDONIENĖ, Institute of Energy and Biotechnology Engineering, Agriculture Academy, Vytautas Magnus University, K. Donelaičio g. 58, LT-44248 Kaunas, Lithuania. indre.bagdoniene@ vdu.lt

\begin{abstract}
The experimental studies were carried out in the most common cowsheds in Lithuania. The cowsheds involved in the research featured different insulation patterns and livestock keeping technologies where cows were kept tied or loose. The efficiency of ventilation system was measured in 7 cowsheds based on the variation in air temperature, air relative humidity (RH) and ammonia. The main problems of microclimate in Lithuanian cowsheds were found to be as follows: a high relative humidity resulting in water vapour condensation on the roof structures; the air temperature is regularly below the recommended minimum of $-7^{\circ} \mathrm{C}$; the air temperature is regularly above the recommended maximum of $25^{\circ} \mathrm{C}$. Optimization of the microclimate in cowsheds concerned, it is recommended to adjust the ventilation intensity based on the difference of air temperatures within the barn and outdoors. During cold months of winter it is recommended to keep the air temperature in semi-insulated cowsheds by $8-11{ }^{\circ} \mathrm{C}$ higher than that outdoors, whereas in uninsulated box-type cowsheds with roof cement - higher by $5-7^{\circ} \mathrm{C}$, and in uninsulated box-type cowsheds with roof metal - higher by only $3-5^{\circ} \mathrm{C}$. During severely freezing periods of outdoor temperature, the air temperature was found not to drop below $-7^{\circ} \mathrm{C}$ only in insulated cowsheds. Whereas during extremely hot days when the outdoor temperature rises above $26-28^{\circ} \mathrm{C}$, the cowsheds of all types (those insulated and uninsulated) were found to be too hot for cows. Consequently, thermal insulation of a cowshed's roof and adjustment of the ventilation intensity are not sufficient for solving the problems caused by heat stress in the cowsheds.
\end{abstract}

Keywords: microclimate, cowshed, ventilation

\section{INTRODUCTION}

The uninsulated (cold) cowsheds used for keeping livestock gained huge popularity in both Lithuania and Europe during the period of last 20 years. These trends of barn development were influenced by the good report on the uninsulated cowsheds in many countries (Bleizgys et al., 2000; Bleizgys and Balezentiene, 2014; Frederick et al., 2008; Ngwabie et al., 2009; Pajumagi et al., 2007; Teye et al., 2008). The implementation of innovative engineering solutions in the field of livestock keeping technologies forces to re-evaluate the potential offered by the uninsulated cowsheds. The farms are constantly getting bigger in size and non-bedded livestock housing designs are rapidly gaining popularity, more and more operations are performed by robotic machines, technological processes of livestock management are undergoing automation, digital systems are being installed in barns for process control and management, cows show increasingly higher levels of production, and the climate is ever-changing - these are the factors that need to be taken into consideration when deciding on the particular construction of the cowshed and its ventilation system. The cowshed is intended for ensuring good animals welfare. It has to be built in an appropriate way and provided with the efficient ventilation system. Most importantly, the air present inside the cowshed must be fresh and clean. During summer-time, it is necessary to control and restrict the exposure of cowshed's interior to direct sunlight. The cowshed must ensure good protection of cows against cold wind, rainfall and snow in winter-time, as well as to make a good shade against hot sunlight in the summer. The optimum temperature and humidity for livestock and maximum gas concentrations allowable in barns are stipulated in the Regulation on technological designing of livestock housing (Lith. Orig.: Galvijų pastatų technologinio projektavimo taisyklèse, Ž $\bar{U}$ TPT 01, 2009). Low temperatures (up to $-7^{\circ} \mathrm{C}$ ) are not harmful for cows, however in order to maintain the modern technological equipment installed in barns in a good operational condition, it is necessary to keep it warm inside of them. The gratings on manure tracks should never become covered with frost, as robots are normally non-operational under low temperatures. Consequently, the need arises for finding an optimal solution: the problem is how to ensure warmth inside the cowshed while maintaining its air fresh and clean at the same time.

The health condition and production level of livestock is highly dependent on the microclimate of the cowshed. As the air temperature and relative humidity rises, animal bodies tend to release less heat which may result in disturbance of their body thermoregulation mechanism leading to risk of overheating. Protection of animals against overheating requires for reduction of relative humidity while increasing air movement speed with the use of natural and artificial ventilation (Caenegem and Wechsler, 2000; Cirnicchiaro et al., 2012).

Animals kept in cold, damp and poorly ventilated houses are known to consume more feeds, gain less weight, show reduced milk yields, and diseases of respiratory system, udder and other health disorders are more common (Ajdini et al., 2015). To ensure a good microclimate and reduce feed consumption, some researchers suggest building the 
insulated cowsheds (Brouček et al., 2009). However, the air inside of them is often humid. When the moisture content is high, ambient conditions are in fact equally harmful under both hot and cold temperatures. It also offers good conditions for bacterial growth which in turn increases the ammonia emissions from manure.

Given the climatic changes forecasted by researchers for the future, mainly associated with the global warming, it is crucial to take all the necessary preventive measures against the adverse effect of solar radiation on the animal welfare. Water sprinkler systems and ventilators are more and more commonly installed in cowsheds along with the different shading systems (use of trees, curtains, etc.) (Angrecka et al., 2017).

Nowadays there are many scientific studies available that offer the analysis of microclimatic factors, their importance and search for the potential ways to improve the microclimate inside the cowsheds as well as to reduce the air pollution (Frederick et al., 2008; Pajumagi et al., 2008; Kang and Lee, 2008; Zhao, 2007; Snell, 2003; Pajumagi et. al., 2008; Joo et al., 2014). Scientists admit that many problems exist as regards analysis and control of the microclimate inside the open-type naturally-ventilated cowsheds. The intensity of ventilation and gas concentrations in a naturallyventilated cowshed are mainly dependent on the wind speed and the difference between the air temperature inside the cowshed and that outdoors (Vtoryi et al., 2016). Temperature is distinguished as one of the most important microclimatic factors that influences other factors, too. The air temperature inside the cowshed is the quality indicator of ventilation efficiency based on which other factors can be assessed as well.

In pursuit of reducing emissions and ensuring a good microclimate inside cowsheds it is highly important to optimize their ventilation intensity (Yi et al., 2018). The ventilation system has to continuously maintain a good microclimate inside the cowshed: to eliminate the moisture excess and to control the condensation.

A rather common problem faced by cowsheds is a high relative humidity, and sometimes high ammonia concentrations. High relative humidity is observed at different times of a year, whereas ammonia concentrations are found to increase in winter. In general, air quality of the cowshed is worse during cold months of a year (Krastev, 2015; Huang and Guo, 2017; Saha et al., 2014; Zhang, 2005). The reason behind this is reducing the ventilation intensity too much in order to prevent low temperatures inside the cowshed. Ammonia concentrations are highly dependent on the air temperature. Emissions of this gas are controlled by means of varying the temperature (Bleizgys and Bagdoniene், 2016; Kaasik and Maasikmets, 2013).

Cowsheds are meant to ensure a suitable microclimate for humans and animals as well as durability of building structures and equipment installed. Unfortunately, cowsheds are often humid and contain high gas concentrations, and their building structures are covered with condensation of water vapour. Modernization of cowsheds often faces some problems associated with their microclimate - how to ensure a suitable temperature and fresh air inside the cowshed by simultaneously maintaining a high level of ventilation.

Objective of the study - to find out the main problems pertinent to the microclimate formation, to evaluate the opportunities for increasing the thermal comfort zone for cows inside cowsheds and to maintain other microclimatic factors at an appropriate level through optimization of heat and mass exchange processes.

\section{OBJECTS AND METHODS}

The experimental studies of microclimate were carried out in livestock cowsheds featuring different constructions. The following are the most common cowsheds in Lithuania that were selected for this purpose:

- Semi-insulated box-type (concrete in manure tracks): housing 215 cows. The cowshed has an insulated roof (Heat Transfer Coefficient for the roof $\left.-0.27 \mathrm{~W} /\left(\mathrm{m}^{2} \mathrm{~K}\right)\right)$, and walls covered with mesh. It is equipped with the slit or slot ventilation system with fresh air entering from the outside through openings in the walls, whereas the polluted air is removed from the cowshed through slit or slot made in the ridge at the rooftop. Adjustment of the ventilation intensity is realized through changing the square area of openings used for air flow. In order to increase air movement within the cowshed during hot weather periods, 10 axial ventilators are activated.

- Semi-insulated box-type (gratings on manure tracks): housing 230 cows. Walls are covered with mesh, and the roof is insulated. The average Heat Transfer Coefficient for the walls is $3.3 \mathrm{~W} /\left(\mathrm{m}^{2} \mathrm{~K}\right)$, and for the roof $-0.45 \mathrm{~W} /\left(\mathrm{m}^{2} \mathrm{~K}\right)$. Fresh air enters the cowshed through the wall openings that are adjusted using curtains, and the polluted air is removed out of it through the adjustable slit or slot made in the ridge at the rooftop.

- Insulated semi-deep: housing 140 cows. Walls of a cowshed are made of the prefabricated reinforced concrete blocks, and cowshed has an overlay which is used as an intermediate deck for storage of straw. The average Heat Transfer Coefficient for the walls and for the roof is below $1.0 \mathrm{~W} /\left(\mathrm{m}^{2} \cdot \mathrm{K}\right)$. This type of cowshed is equipped with the natural ventilation system with fresh air entering through openings available in walls that are covered with the mesh, and afterwards exiting through a single channel. Adjustment of the ventilation intensity is controlled by the valve fitted in the channel.

- Insulated tied cowshed (with overlay): housing 110 cows. This is an insulated cowshed with the overlay which is used for storage of straw. There are double-pane glass windows installed in the walls. The average Heat Transfer Coefficient for the walls and for the roof is below $1.0 \mathrm{~W} /\left(\mathrm{m}^{2} \cdot \mathrm{K}\right)$. This type of cowshed is equipped with the natural ventilation system with fresh air entering through openings available in walls that are covered with the mesh, and afterwards exiting through a single channel. Adjustment of the ventilation intensity is controlled by the valve fitted in the channel. 
- Insulated tied cowshed (without overlay): housing 180 cows. This is an insulated cowshed without the overlay. It is equipped with the natural ventilation system with fresh air entering through openings available in walls, and the polluted air exiting from the cowshed through slit made in the ridge at the rooftop.

- Uninsulated box-type (roof cement): housing 200 cows. The lower sections of cowshed's walls are made of the prefabricated reinforced concrete blocks, whereas the upper sections of walls are built from $0.10 \mathrm{~m}$ width single-cut wood planks that are spaced by $0.02 \mathrm{~m}$ wide slots to ensure entrance of fresh air into a cowshed. The roof is covered with concrete slating. The average Heat Transfer Coefficient for the walls as well as for the roof is $4.5 \mathrm{~W} /\left(\mathrm{m}^{2} \cdot \mathrm{K}\right)$. Fresh air enters a cowshed through openings left between the planks, and the polluted air is removed through $0.40 \mathrm{~m}$ width slit made in the ridge at the rooftop.

- Uninsulated box-type (roof metal): housing 220 cows. This type of a cowshed as uninsulated walls and roof which is covered with metal roofing. It is equipped with the ridge/slit and slot ventilation system with fresh air entering the cowshed through openings available in walls and covered with the mesh, and exiting through a slit in the ridge at the rooftop. Air movement is controlled by varying the square area of openings available in walls.

The following microclimatic factors of cowsheds have been studied at different periods of the year: air temperature; relative humidity of the air; and ammonia concentration. Air temperature and relative humidity were recorded every hour using programmable stand-alone temperature/humidity data loggers MicroLite LITE5032P-RH Fourtec: temperature range -40 to $80{ }^{\circ} \mathrm{C}$, temperature accuracy $\pm 0.3{ }^{\circ} \mathrm{C}$; temperature resolution $0.02{ }^{\circ} \mathrm{C}$, humidity range 5 to $95 \%$, humidity accuracy $\pm 2 \% \mathrm{RH}$, humidity resolution $0.05 \% \mathrm{RH}$ (Made in Germany).

Ammonia concentration was measured using Aeroqual gas analyser Series 500: Range 0-100 ppm, minimum detection limit $0.2 \mathrm{ppm}$, accuracy of factory calibration $\pm 0.5 \mathrm{ppm}$ (Made in New Zealand).

In a course of investigation, the microclimatic factors were measured for the record at 5 to 7 locations inside the cowsheds, and at 2 locations outside of them. Each farm was involved in investigation for the full keeping-in-the-barn period, and in case livestock was kept in a cowshed all year round, the microclimatic factors were measured in summer too. When analysing air temperature, relative humidity and ammonia concentrations inside the cowsheds, the efficiency of ventilation systems used was evaluated.

The obtained data was analysed using methods of polynomial correlation and regression. Data reliability was validated on the basis of a Student's criterion. Standard error and minimum limit for reliability difference were calculated at $\mathrm{p}<0.05$ level of statistical significance.

\section{RESULTS AND DISCUSSION}

Any ventilation system must ensure and maintain a good microclimate in a cowshed by removing the excess of moisture, harmful gases and controlling the condensation. The studies under consideration that were carried out in the most common cowsheds used in Lithuania showed that inappropriate air temperature and high ammonia concentrations is not the main problem here; the main problem is high air humidity levels inside these cowsheds. The most humid air was found inside the insulated tied cowsheds with the overlay (ceiling). The temperature in this type of cowsheds usually meets the requirements. However, when the temperature outside decreases, the positive temperature inside of a cowshed is achieved by means of reducing the ventilation intensity which in turn leads to worsening indicators of air freshness and cleanliness. When the outside temperature falls down to $0{ }^{\circ} \mathrm{C}$, the difference between outside and inside temperature increases to $14.6{ }^{\circ} \mathrm{C}$, and when it is extremely freezing outdoors $\left(-23.0^{\circ} \mathrm{C}\right)$, the temperature difference seems to increase to as much as $29^{\circ} \mathrm{C}$ (See Fig. 1). It means that ventilation intensity is insufficient. For this reason relative air humidity amounts for nearly $100 \%$, and in case of even a slight drop down in air temperature, the condensation of water vapour on different building structures is obvious. When the weather is cold outside (temperatures below $0{ }^{\circ} \mathrm{C}$ ), air relative humidity inside of a tied cowshed almost always exceeds the recommended levels. Although low temperatures are known to be less harmful for cows than high air humidity, a wrong solution is often made by trying to preserve higher temperatures inside a cowshed despite it leads to increased air humidity.

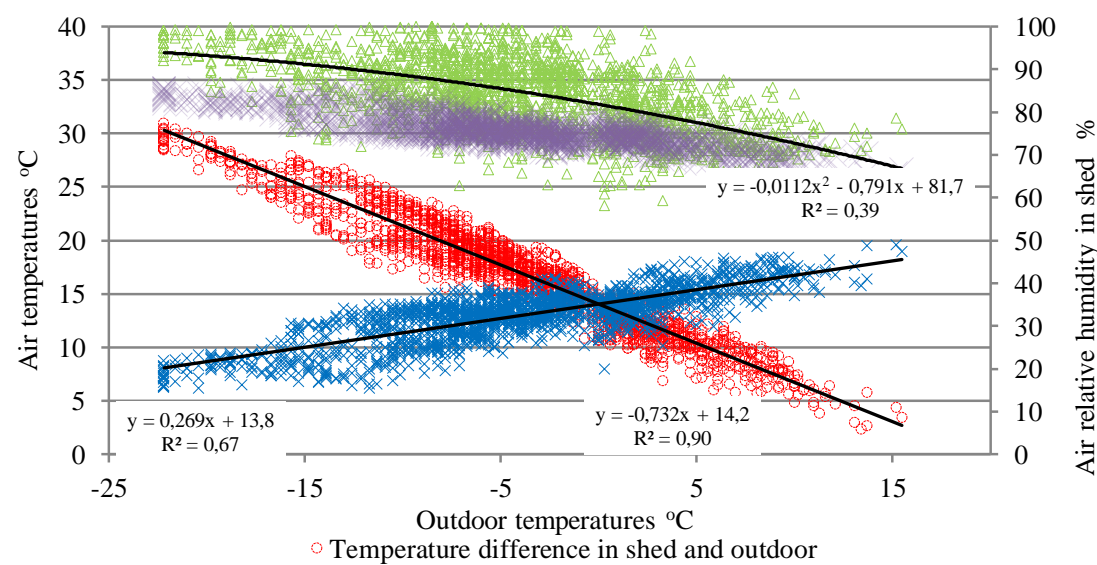

Figure 1. The dynamics of air temperature and relative humidity inside an insulated tied shed (with overlay) in relation to the outdoor temperatures. 
The air inside of uninsulated cowsheds was found to be generally dryer (Fig. 2). In summertime air humidity is not very high inside of cold (uninsulated) cowsheds, but it is increased as soon as the weather gets cold and ventilation channels are closed too much. Then, the difference between the inside and outside temperatures increases to which in turn leads to occurrence of condensation on roof structures. During periods of extremely cold weather, the difference between the inside and outside temperatures increases to $5-6^{\circ} \mathrm{C}$, and during hot weather periods it is by $1.8-3.7^{\circ} \mathrm{C}$ cooler inside this type of a cowshed. When air temperature rises inside of an uninsulated cowshed to the level that exceeds outside air temperature by $6.5-7.0{ }^{\circ} \mathrm{C}$, a condensation occurs on internal surfaces of a roof and walls which is harmful not only for the structures of the cowshed but for the animals kept inside, too.

During winter air temperature inside of an uninsulated cowshed may drop even below $-10.0{ }^{\circ} \mathrm{C}$ and last for entire decade. When air temperature drops down, it is necessary to find an efficient way to reduce body heat release to prevent from disturbance of cow's energy balance. During hot weather periods, it is a little bit cooler inside of a cowshed than outdoors: the daily average temperature inside is by $1{ }^{\circ} \mathrm{C}$ lower when compared to that outside. Inside air temperature rises as high as to $28-29^{\circ} \mathrm{C}$ for only several hours per day.

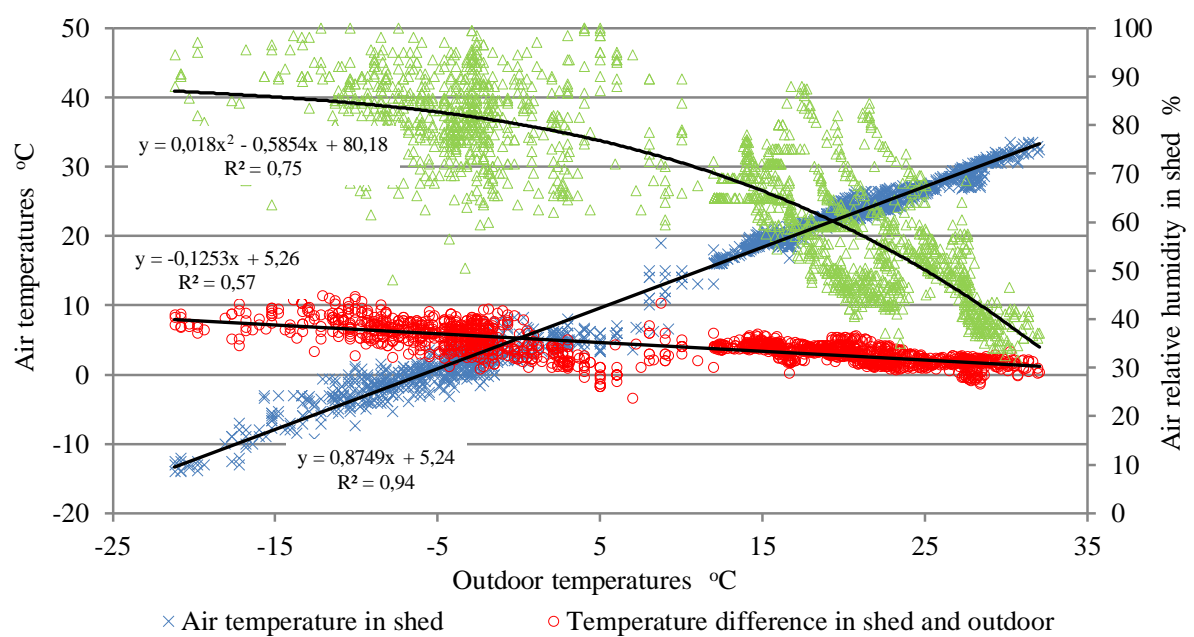

Figure 2. The dynamics of air temperature and relative humidity inside an uninsulated cowshed box-type (roof metal) in relation to the outdoor temperatures.

The microclimatic factors in semi-insulated cowsheds (with only roof insulated) were also found to worsen during cold weather periods. Air temperature inside of cowsheds fell below $0{ }^{\circ} \mathrm{C}$ when it was colder outside than $-6.4--7.5{ }^{\circ} \mathrm{C}$. The coldest period in a cowshed was found to be at 7:00 to 10:00 a.m., and the hottest period in summertime -at 3:00 to 7:00 p.m. Air relative humidity in semi-insulated cowsheds varied in a wide range of $31.5 \%$ to $96.8 \%$. Air humidity often exceeded the recommended level by several percent. The most humid air inside of this type of cowsheds was found in spring and autumn (in September), whereas during cold season it was found to meet the requirements. During summertime, air humidity inside a cowshed was found to increase at night and in the morning (0:00 to 9:00 a.m.). Air humidity inside a cowshed was dependent on the outside air humidity, although this relationship was not strong. It was mainly determined by the change in air movement inside a cowshed depending on the change in air temperature. With the decrease in the outside air temperature, air humidity increases significantly. Decrease in air circulation inside a cowshed caused the difference between the inside and outside temperature to increase. When the air temperature outside fell down from $+15^{\circ} \mathrm{C}$ to $-1{ }^{\circ} \mathrm{C}$, the temperature difference increases from $0.5^{\circ} \mathrm{C}$ to $8.0^{\circ} \mathrm{C}$, and when the temperature reached cold of $19{ }^{\circ} \mathrm{C}$, the temperature difference increased to almost $11.7^{\circ} \mathrm{C}$. Despite such a big temperature difference, no condensate was observed to occur on insulated roof structures. However, when the temperature difference exceeded $7{ }^{\circ} \mathrm{C}$, condensation occurred on the uninsulated roof structures covering the slot in the ridge at the rooftop.

The main reason lying behind a bad microclimate inside cowsheds under consideration was found to be not so much a poorly built ventilation system, but an incorrect their use at too low intensity. The control of ventilation systems installed in cowsheds doesn't require for complex and/or expensive devices that are normally necessary for analysis of air quality indicators. It is recommended to adjust the intensity of ventilation based on the difference between cowshed inside and outside temperatures.

Correct adjustment and control of ventilation intensity may offer a good solution to finding a right balance between the air temperature and the factors of air cleanliness (see Fig. 3). In a tied cowshed, air temperature doesn't fall below $0{ }^{\circ} \mathrm{C}$ preventing high air humidity as well as occurrence of condensate on the roof structures.

Under sufficiently intensive ventilation of a cowshed, a strong correlation between air relative humidity inside and outside the cowshed is obtained $\left(\mathrm{R}^{2}=0.861\right)$. Air humidity increases inside a cowshed for only short periods of time and meets the requirements in almost all the seasons of the year. It is possible to achieve not cold and not humid environment inside a cowshed with fresh and clean air containing low concentrations of gases, the same being valid for a tied-type cowshed as well. The most important thing is to ensure that cowshed has no overlay and offers more space per animal, that there is no accumulation of urine, and as little as possible of open surfaces capable of evaporating water and various gases (mostly, ammonia). 


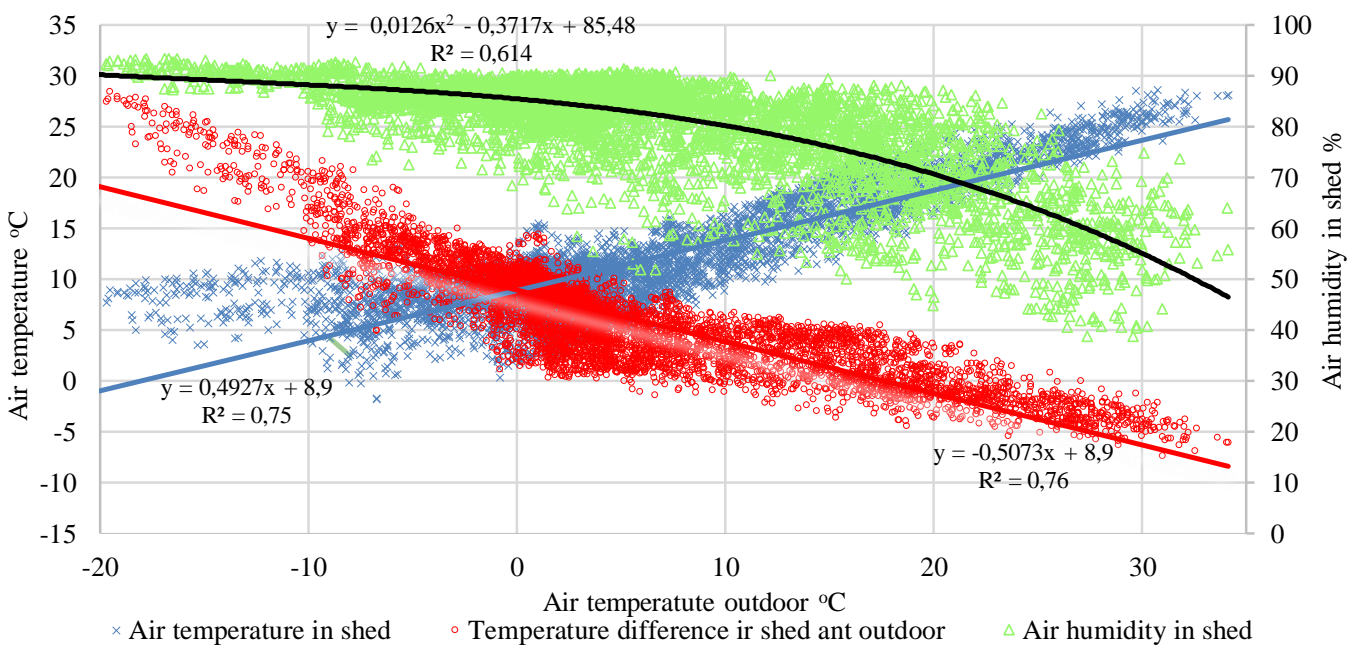

Figure 3. The dynamics of air temperature and relative humidity inside an insulated tied cowshed (without overlay) in relation to the outdoor temperatures.

The insulated cowsheds (tied, semi-deep) and semi-insulated box-type cowsheds were found to maintain good inside air temperatures during winter months, and during hot summer days they showed inside air temperatures to be higher by several degrees than recommended. The cold (uninsulated) cowsheds showed the widest range of temperature variation: from $-14.0^{\circ} \mathrm{C}$ to $33.0^{\circ} \mathrm{C}$, whereas this variation was found to be a little bit smaller for the insulated cowsheds (their maximum air temperature was by several degrees lower than that of the cold cowsheds, and during cold weather periods the temperature did not fall below $0{ }^{\circ} \mathrm{C}$ ). During hot weather periods, the inside air temperature was found to be too high in all types of cowsheds, with the uninsulated cowsheds exceeding the recommended maximum temperature $\left(25{ }^{\circ} \mathrm{C}\right.$ ) by $5-8{ }^{\circ} \mathrm{C}$, and the insulated cowsheds - by $4-5{ }^{\circ} \mathrm{C}$. Different temperatures inside cowsheds are determined by the structure of a shed, the insulation of building fences, the density of animals kept, and the intensity of ventilation. The air temperature comparison in cowsheds with the insulated roof and in the uninsulated cowsheds (roof cement and roof metal) revealed significant temperature differences only during freezing weather periods, whereas during hot weather periods this temperature difference was minor. Figure 4 presents temperature comparison in detail. This figure shows variation of air temperatures found in different types of cowsheds, where their inside temperatures were calculated based on the established correlation between the air temperature inside a cowshed and the air temperature outdoors. The maximum temperature difference was found to exist during the cold season. With the increase in the outside temperature, the temperature differences in different types of cowsheds tend to decrease. Whenever the heat reaches $30^{\circ} \mathrm{C}$ outdoors it becomes too hot for animals in all types of cowsheds under consideration, even those having an insulated roof.

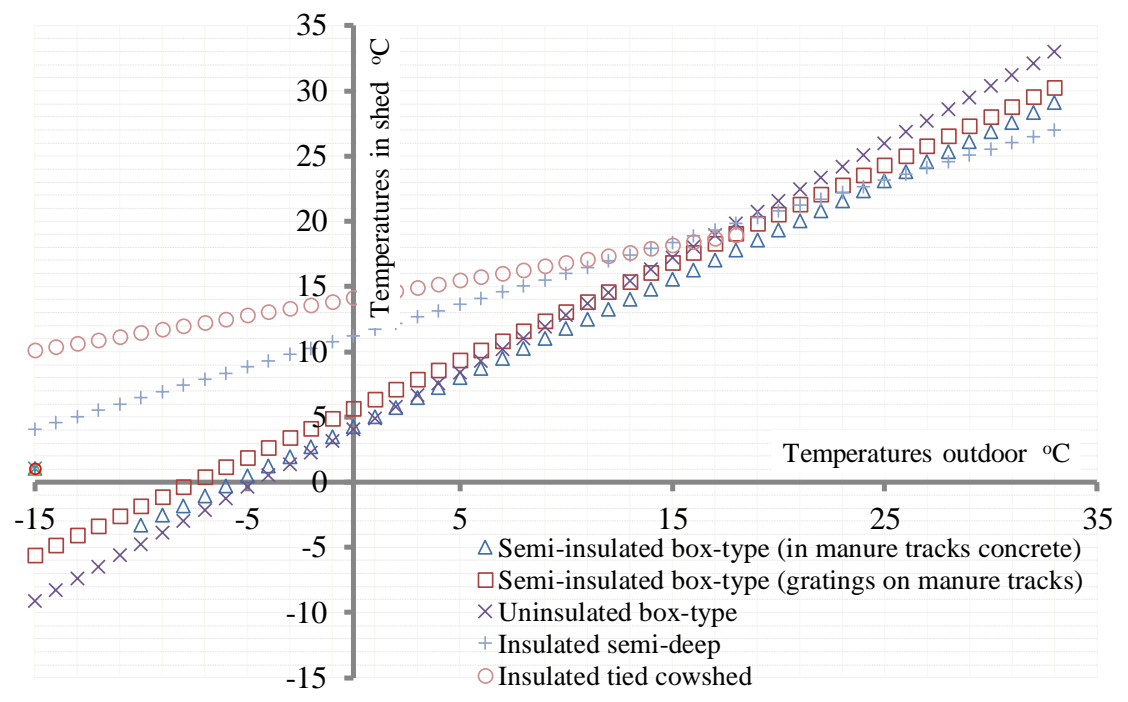

Figure 4. Air temperatures in cowsheds in relation to the outdoor temperatures.

Ammonia concentration was found to vary in cowsheds under consideration in range of 0 to $14 \mathrm{ppm}$ (Fig. 5), meaning that standard values set (20 ppm) were not exceeded. The lowest concentration was found in uninsulated boxtype cowsheds, and the highest - in tied cowsheds. Air temperature has a significant effect on the rate of ammonia evaporation from manure. For this reason ammonia concentration tends to increase with the increasing air temperature. However, if the cowshed is ventilated at a sufficiently intensive level, ammonia concentration will remain low even during periods of hot weather. However if ventilation is insufficient, it may cause ammonia concentrations to be high even at 
low air temperatures. Accordingly, during periods of cold weather, ammonia concentrations were found to increase in tied cowsheds.

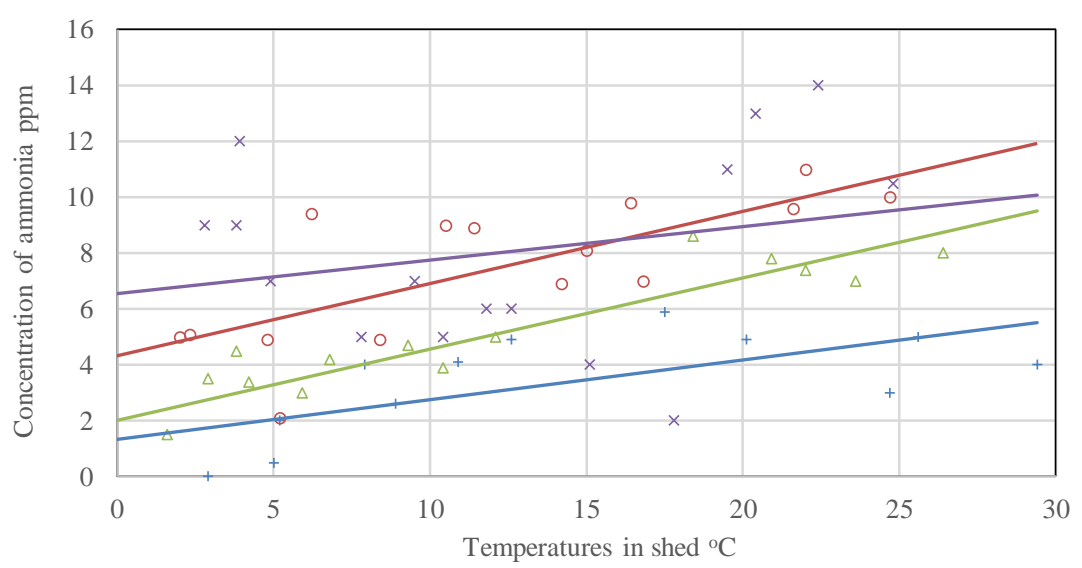

$$
\begin{aligned}
& \text { + Uninsulated box-type } \\
& y=0,1425 x+1,32 \\
& \mathrm{R}^{2}=0,51 \\
& \text { - Semi-deep } \\
& y=0,2586 x+4,31 \\
& \mathrm{R}^{2}=0,54 \\
& y=0,1198 x+6,53 \\
& \mathrm{R}^{2}=0,16
\end{aligned}
$$

Figure 5. Ammonia concentrations in cowsheds with relation to air temperatures inside of them.

Proper ventilation is of utmost importance for any type of a cowshed. Most of the ventilation intensity is required for the removal of excess of water vapour present inside of a cowshed. Consequently, it is absolutely sufficient to adjust the ventilation intensity inside of livestock sheds based on the water vapour content. If low air humidity is ensured inside, ammonia concentration will consequently be low, too.

\begin{tabular}{|c|c|c|c|c|}
\hline Shed & $\begin{array}{c}\text { When were air } \\
\text { temperatures too low } \\
\text { in a shed? } \\
t_{o}<-7^{\circ} C\end{array}$ & $\begin{array}{c}\text { When were air } \\
\text { temperatures too } \\
\text { high in a shed? } \\
t_{o}>25^{\circ} \mathrm{C} \\
\end{array}$ & $\begin{array}{l}\text { When was air } \\
\text { relative humidity } \\
\text { too high in a } \\
\text { shed? }\end{array}$ & $\begin{array}{l}\text { Are there good conditions } \\
\text { for condensation of water } \\
\text { vapour on roof structures? }\end{array}$ \\
\hline $\begin{array}{l}\text { Semi-insulated box-type (in } \\
\text { manure tracks concrete) }\end{array}$ & $\mathrm{t}_{\mathrm{o}}<-14.9^{\circ} \mathrm{C}$ & $\mathrm{t}_{\mathrm{o}}>27.7^{\circ} \mathrm{C}$ & $\begin{array}{l}\mathrm{t}_{\mathrm{o}}<-4^{\circ} \mathrm{C} \\
\Delta t>10^{\circ} \mathrm{C}\end{array}$ & Not good \\
\hline $\begin{array}{l}\text { Semi-insulated box-type } \\
\text { (gratings on manure tracks) }\end{array}$ & $\mathrm{t}_{\mathrm{o}}<-17.0^{\circ} \mathrm{C}$ & $\mathrm{t}_{\mathrm{o}}>26.5^{\circ} \mathrm{C}$ & $\begin{array}{l}\mathrm{t}_{\mathrm{o}}<-6^{\circ} \mathrm{C} \\
\Delta t>9^{\circ} \mathrm{C}\end{array}$ & Good enough \\
\hline $\begin{array}{l}\text { Uninsulated box-type (roof } \\
\text { cement) }\end{array}$ & $\mathrm{t}_{\mathrm{o}}<-14.1^{\circ} \mathrm{C}$ & $\mathrm{t}_{\mathrm{o}}>26.3^{\circ} \mathrm{C}$ & $\begin{array}{c}\mathrm{t}_{\mathrm{o}}<-12{ }^{\circ} \mathrm{C}, \\
\Delta t>7{ }^{\circ} \mathrm{C}\end{array}$ & Not good \\
\hline $\begin{array}{l}\text { Uninsulated box-type (roof } \\
\text { metal) }\end{array}$ & $\mathrm{t}_{\mathrm{o}}<-12.4^{\circ} \mathrm{C}$ & $t_{0}>25.9^{\circ} \mathrm{C}$ & $\begin{array}{c}\mathrm{t}_{\mathrm{o}}<-10^{\circ} \mathrm{C} \\
\Delta t>5^{\circ} \mathrm{C}\end{array}$ & Very good \\
\hline Insulated semi-deep & was not & $\mathrm{t}_{\mathrm{o}}>28.5^{\circ} \mathrm{C}$ & $\begin{aligned} \mathrm{t}_{\mathrm{o}} & <6^{\circ} \mathrm{C} \\
\Delta t & >13^{\circ} \mathrm{C}\end{aligned}$ & Not good \\
\hline $\begin{array}{l}\text { Insulated tied cowshed (with } \\
\text { overlay) }\end{array}$ & was not & - & $\begin{array}{l}\mathrm{t}_{\mathrm{o}}<11^{\circ} \mathrm{C} \\
\Delta t>8^{\circ} \mathrm{C}\end{array}$ & Very good \\
\hline $\begin{array}{l}\text { Insulated tied cowshed } \\
\text { (without overlay) }\end{array}$ & was not & $t_{0}>28.6^{\circ} \mathrm{C}$ & $\begin{aligned} \mathrm{t}_{\mathrm{o}} & <2{ }^{\circ} \mathrm{C} \\
\Delta t & >14^{\circ} \mathrm{C}\end{aligned}$ & Good enough \\
\hline
\end{tabular}

In cowsheds, a poor microclimate mainly forms due to high air humidity (Table 1). The less any cowshed is insulated, the lower air temperatures prevail, and the dryer air is inside of it. Well insulated cowsheds feature significantly increasing air humidity levels with the decrease of air temperature outside. These results are determined by the incorrect adjustment of the square area of air supply channels and continuous maintenance of incorrect ventilation intensity. Reduction of ventilation intensity inside of a cowshed leads to decrease in its air quality. Moreover, it is not sufficient to install ventilation systems in cowsheds; they must be properly controlled while taking into account changing weather conditions. High air humidity is often observed in cowsheds where the ventilation equipment is used unable of operating efficiently at low ambient temperatures. During cold weather periods, to prevent inside air temperature from falling down, the ventilation intensity is often restricted in a cowshed. Such cowsheds (tied cowsheds, box-type with gratings on manure tracks) are humid and face significant condensation of water vapour on roof structures.

Table 1. Outdoor climate conditions that cause unfavourable microclimate in sheds $(\mathrm{P}<0.05)$

$\mathrm{t}_{\mathrm{o}}$ - air temperature outdoor, ${ }^{\circ} \mathrm{C}$;

$\mathrm{t}_{\mathrm{i}}$ - air temperature in shed, ${ }^{\circ} \mathrm{C}$;

$\Delta t$ - differences of air temperatures in shed and outdoor $\left(\mathrm{t}_{\mathrm{i}}-\mathrm{t}_{\mathrm{o}}\right),{ }^{\circ} \mathrm{C}$.

When dealing with microclimate in cowsheds, the dynamics of inside air parameters must be analysed, and ventilation efficiency must be afterwards evaluated based on this analysis. Of all the varied air parameters (air temperature, relative humidity) air temperature represents the best indicator for the evaluation of ventilation. Control of ventilation systems installed in cowsheds does not require for complex and/or expensive devices that are normally necessary for analysis of air quality indicators. It is recommended to adjust the intensity of ventilation inside a cowshed based on the difference between its inside and outside temperatures. Consequently, based on the difference between inside and outside air temperatures, the optimal algorithm for the adjustment of ventilation intensity needs to be developed for every individual cowshed, while taking into account thermal characteristics of its building structures and animals kept in it. 


\section{CONCLUSIONS}

The main microclimatic problems characteristic for the cowsheds commonly found in Lithuania are as follows: high relative air humidity; occurrence of water vapour condensation on roof structures; air temperature inside of a cowshed is below the minimum recommended of $-7{ }^{\circ} \mathrm{C}$; air temperature inside of a cowshed exceeds the maximum recommended of $25^{\circ} \mathrm{C}$. Air humidity will be low inside of a cowshed if it is ventilated at a sufficient intensity. Most of the ventilation intensity is required for the removal of excess of water vapour present inside of a cowshed. Consequently, it is absolutely sufficient to adjust the ventilation intensity inside of a cowshed based on the water vapour content. If low air humidity is ensured inside, ammonia concentration will consequently be low, too.

Formation of condensation of water vapour on roof structures is successfully prevented by means of sufficiently intensive ventilation. It is recommended to adjust the ventilation intensity based on the difference between air temperatures inside and outside of a cowshed. During cold weather periods, in semi-insulated cowsheds, it is recommended to maintain the air temperature by $8-11{ }^{\circ} \mathrm{C}$ higher than outside, whereas in uninsulated box-type with roof cement - by $5-7^{\circ} \mathrm{C}$, and in uninsulated box-type with roof metal - only by $3-5{ }^{\circ} \mathrm{C}$.

It is rather difficult to achieve that inside air temperature is positive and air fresh and clean with low moisture content in all types of cowsheds under consideration. Optimal adjustment of ventilation intensity in insulated cowsheds during cold weather periods prevents temperature falling below $-7{ }^{\circ} \mathrm{C}$, whereas in uninsulated cowsheds air temperature may fall as low as below $-10^{\circ} \mathrm{C}$. However, this will not last long: only up to 10-14 days.

During hot weather periods when the outdoor temperature rises above $26-28{ }^{\circ} \mathrm{C}$, it becomes too hot in all the types of cowsheds (those insulated and uninsulated). In the face of the ever-changing climate, a problem of high temperatures inside cowsheds will gain even greater relevance in Lithuania. Thermal insulation of a cowshed's roof and adjustment of ventilation intensity seem not to solve the problem of heat stress in cowsheds. For this purpose other efficient cooling means will be needed such as artificial misting or fogging systems.

\section{REFERENCES}

1. Angrecka S., Herbut P., Nawalany G., Sokołowski P. 2017. The impact of localization and barn type on insolation of sidewall stalls during summer. Journal of Ecological Engineering, Vol. 18, Iss. 4, pp. 60-66. https://doi.org/10.12911/22998993/74398

2. Ajdini S., Berberi P., Ceroni V., Sherifi K. 2015. Hygienical factors of the enviroment and bronchopneumonia in calves. Anglisticum journal, Vol. 4(6), pp. 293-298.

3. Bleizgys R., Kavolèlis B., Bakutis B., Monstvilienė E. 2000. Neapšiltintos karvidès mikroklimatas ir sanitarija. Žemès ūkio inžinerija, No. 32 (2), p. 59-70. (In Lithuanian)

4. Bleizgys R., Bagdoniene I. 2016. Control of ammonia air pollution through the management of thermal processes in cowsheds. Science of the total environment, Vol. 568, pp. 990-997. https://doi.org/10.1016/j.scitotenv.2016.05.017

5. Bleizgys R., Baležentienè L. 2014. Assessments of biogenic gas emission procesess in cowsheds. Polish Journal of Environmental Studies, Vol. 23, Iss. 4, pp. 1107-1114.

6. Brouček J., Novák P., Vokřálová J., Šoch M., Kišac P., Uhrinčat M. 2009. Effect of high temperature on milk production of cows from free-stall housing with natural ventilation. Slovak Journal of Animal Science, Vol. 42 (4), pp. 167 - 173.

7. Caenegem L. V., Wechsler B. (2000). Stallklimawerte und ihre Berechnung. FAT. Tänikon TG, S. 89.

8. Cirnicchiaro N., Rentiz D.G., Whitet B.J., Babcock A.H., Fox J.T. 2012. Associations between weather conditions during the first 45 days after feedlot arrival and daily respiratory disease risks in autumn - placed feeder cattle in the United States. Journal of Animal Science 90(4), pp.1328-1337. https://doi.org/10.2527/jas.2011-4657

9. Frederick K. T., Hautala M., Pastell M., Praks J., Eerma I., Poikalainen V., Pajumagi A., Kivinen T., Ahokas J. 2008. Microclimate and ventilation in Estonian and Finnish dairy buildings. Energy and Buildings, Vol. 40, pp. $1194-1201$. https://doi.org/10.1016/j.enbuild.2007.10.017

10. Huang D., Guo H. 2017. Diurnal and seasonal variations of odor and gas emissions from a naturally ventilated free-stall dairy barn on the Canadian Prairies. Journal of the Air \& Waste Management Association, Vol. 67(10), pp. 1092-1105. https://doi.org/10.1080/10962247.2017.1329172

11. Yi Q., Zhang G., König M., Janke D., Hempel S., Amon T. 2018. Investigation of discharge coefficient for wind-driven naturally ventilated dairy barns. Energy and Buildings, Vol. 165(15), pp. 132-140. https://doi.org/10.1016/j.enbuild.2018.01.038

12. Joo H.S., Ndegwa P.M., Heber A.J., Bogan B.W., Ni J.Q., Cortus E.L., Ramirez-Dorronsoro J.C. 2014. A direct method of measuring gaseous emissions from naturally ventilated dairy barns. Atmospheric Environment, Vol. 86, pp. 176-186. https://doi.org/10.1016/j.atmosenv.2013.12.030

13. Kaasik A., Maasikmets M. 2013. Concentrations of airborne particulate matter, ammonia and carbon dioxide in large scale uninsulated loose housing cowsheds in Estonia. Biosystems engineering, Vol. 114, pp. $223-231$. https://doi.org/10.1016/j.biosystemseng.2013.01.002

14. Kang J.H., Lee S.J. 2008. Improvement of natural ventilation in a large factory building using a louver ventilator. Building and Environment, Vol. 43 (12), pp. 2132-2141. https://doi.org/10.1016/j.buildenv.2007.12.013

15. Krastev K. 2015. Ecological assessment of season dynamics of microclimate in a building for 200 cows. Bulgarian Journal of Animal Husbandry, pp. 37-41. 
16. Ngwabie N.M., Jeppsson K.-H., Nimmermark S., Swensson C., Gustafsson G. 2009. Multi-location measurements of greenhouse gases and emission rates of methane and ammonia from a naturally-ventilated barn for dairy cows. Biosystems Engineering, Vol. 103(1), pp. 68-77. https://doi.org/10.1016/j.biosystemseng.2009.02.004

17. Pajumagi A., Poikalainen V., Veerma I., Praks J. 2008. Spatial distribution of air temperature as a measure of ventilation efficiency in large uninsulated cowshed. Building and Environment, Vol. 43, pp. 1016-1022. https://doi.org/10.1016/j.buildenv.2007.02.015

18. Saha C.K., Ammon C., Berg W., Fiedler M., Loebsin C., Sanftleben P., Brunsch R., Amon T. 2014. Seasonal and diel variations of ammonia and methane emissions from a naturally ventilated dairy building and the associated factors influencing emissions. Science of the Total Environment, Vol. 468 -469, pp. 53-62. https://doi.org/10.1016/j.scitotenv.2013.08.015

19. Snell H.G.J, Seipelt F., Van den Weghe H.F.A. 2003. Ventilation Rates and Gaseous Emissions from Naturally Ventilated Dairy Houses. Biosystems Engineering, Vol. 86(1), pp. 67-73. https://doi.org/10.1016/S1537-5110(03)00113-2

20. Teye K. F., et al. 2008. Microclimate and ventilation in Estonian and Finnish dairy buildings. Energy and Buildings, Vol. 40(7), pp. 1194-1201. https://doi.org/10.1016/j.enbuild.2007.10.017

21. Vtoryi V., Vtoryi S., Lantsova E., Gordeev V. 2016. Effect of water conditions on content of carbon dioxide in barns. Engineering for rural development, Jelgava, pp. 437-431.

22. Zhang G., Strøm J.S., Li B., Rom H.B., Morsing S., Dahl P., Wang C. 2005. Emission of ammonia and other contaminant gases from naturally ventilated dairy cattle buildings. Biosystems Engineering, Vol. 92(3), pp. 355-364. https://doi.org/10.1016/j.biosystemseng.2005.08.002

23. Zhao L.Y., Bruger M.F., Manuron R.B. 2007. Variations of air quality of New Ohio dairy facilities with natural ventilation systems. Aplied Engineering in Agriculture, Vol. 23(3), pp. 339-346. https://doi.org/10.13031/2013.22684

24. Ž $\bar{U}$ TPT 01:2009. Galvijų pastatų technologinio projektavimo taisyklès, patvirtintos Lietuvos Respublikos žemès ūkio ministro 2009 m. rugpjūčio 21 d. įsakymu Nr. 3D-602. (In Lithuanian). 